\title{
Erratum to: Serial passage in ducks of a low-pathogenic avian influenza virus isolated from a chicken reveals a high mutation rate in the hemagglutinin that is likely due to selection in the host
}

Callie Ridenour ${ }^{1,2} \cdot$ Susan M. Williams ${ }^{1} \cdot$ Les Jones $^{2}$.

S. Mark Tompkins ${ }^{2} \cdot$ Ralph A. Tripp $^{2} \cdot$ Egbert Mundt $^{1}$

Published online: 2 April 2016

(C) Springer-Verlag Wien 2016

Erratum to: Arch Virol (2015) 160:2455-2470

DOI 10.1007/s00705-015-2504-1

Research reported in this publication was partially supported by the National Institute of Allergy and Infectious Diseases under award number HHSN266200700006C. The content is solely the responsibility of the authors and does not necessarily represent the official views of the National Institutes of Health.

The online version of the original article can be found under doi:10.1007/s00705-015-2504-1.

Egbert Mundt

mundtegbert@gmail.com

1 Department of Population Health, Poultry Diagnostic and Research Center, University of Georgia, Athens 30603, GA, USA

2 Department of Infectious Diseases, College of Veterinary Medicine, University of Georgia, Athens 30603, GA, USA 